\title{
PENAPISAN HEMAGGLUTININ DARI ALGA HIJAU GENUS Codium (Chlorophyceae, Codiaceae)
}

\section{SCREENING OF HEMAGGLUTININS FROM THE GREEN ALGAL GENUS Codium (Chlorophyceae, Codiaceae)}

\author{
Danar Praseptiangga ${ }^{1)}$ \\ 1) Staf Pengajar Program Studi Ilmu dan Teknologi Pangan, Fakultas Pertanian \\ Universitas Sebelas Maret Surakarta \\ email: dpraseptiangga@uns.ac.id
}

\begin{abstract}
Lectins (hemagglutinins) are widely distributedin nature and also good candidates in such prospecting of marine algae. The most important property of a lectin is the ability to bind to carbohydrates and hence agglutinate cells.Lectins are useful as convenient tools to discriminate differences in carbohydrate structures and reveal various biological activities through binding and interacting to carbohydrates. There is a considerable interest in discovering and isolating novel lectins from the perspective of their applications, particularly in glycomics and in the medical field. Crude lectin fractionsfrom six green algae of the genus Codium were prepared and examined for their hemagglutination activities with trypsin-treated rabbit erythrocytes. The positive result of five crude lectin fractions of the green algal genus Codium on hemagglutination assayindicates that lectins (hemagglutinins) are present in these species. However, further researches on lectins purificationand characterization of their biochemical propertiesare still needed.
\end{abstract}

Keywords: lectins (hemagglutinins), thegreen algal genus Codium, hemagglutination activity

\section{ABSTRAK}

Lektin (hemagglutinin) tersebar secara luas di alam dan memiliki potensi yang baik terkait dengan prospeksinya dari alga laut. Sifat terpenting lektin adalah kemampuannya untuk mengikat karbohidrat dan mengaglutinasi sel. Lektin dapat berguna sebagai alat yang mudah digunakan untuk menunjukkan perbedaan struktur karbohidrat dan mempunyai berbagai macam aktifitas biologis terkait dengan pengikatan dan interaksinya dengan karbohidrat, sehingga terdapat ketertarikan yang besar dalam upaya untuk menemukan dan mengisolasi lektin baru dari perspektif penggunaan lektin, khususnya dalam bidang glycomics dan medis. Fraksi kasar lektin dari enam spesies alga hijau genus Codium disiapkan dan diuji aktifitas hemaglutinasinya dengan menggunakan trypsin-treated rabbit erythrocytes. Hasil positif pada limaspesies alga hijau genus Codium yang diuji dalam hemagglutination assay mengindikasikan keberadaan lektin (hemagglutinin) pada spesies-spesies tersebut. Namun demikian, masih diperlukan penelitian lebih lanjut mengenai pemurnian lektin dan karakterisasi sifat biokimianya.

Kata kunci : lektin (hemagglutinin), alga hijau genus Codium, aktifitas hemaglutinasi

\section{PENDAHULUAN}

Lektin (hemagglutinin) atau carbohydrate-binding proteins tersedia melimpah di alam pada berbagai organisme, dari tanaman, hewan, bakteri, fungi, virus, sampai ke manusia dan memegang peranan penting sebagai molekul pengenal atau pelacak dalam interaksi antara sel-sel atau sel-matriks (Hori et al., 2000, Sharon dan Lis, 2003).Lektin mengikat karbohidrat dengan spesifisitas yang tinggi, namun tidak memiliki aktifitas katalitik seperti halnya enzim. Lektin berbeda dengan antibody dan bukan merupakan produk dari respon imun. Setiap molekul lektin biasanya mempunyai dua atau lebih carbohydrate-binding sites, oleh karena itu ketika mereka bereaksi dengan sel, sebagai contoh eritrosit, mereka tidak hanya akan berinteraksi dengan gula yang ada pada pada permukaan, melainkan juga akan berinteraksi membentuk ikatan silang dengan molekul-molekul polisakarida atau glikoprotein dan menginduksi terjadinya presipitasi dalam interaksinya tersebut yang merupakan fenomena yang disebut sebagai aglutinasi (Sharon dan Lis, 2003, Brooks et al., 2002., Varki et al., 1999). Aglutinasi eritrosit oleh lektin (hemagglutinin) adalah sifat utama dari protein ini dan umum digunakan secara rutin untuk deteksi dan karakterisasi lektin (hemagglutinin).

Sejumlah kegunaan lektin telah ditemukan dalam riset kimiawi dan biokimiawi, termasuk kegunaannya dalam proses pemurnian dan analisa glikoprotein 
yang memberikan kontribusi signifikan terhadap bidang glycobiology serta sebagai alat untuk memecahkan kode struktur karbohidrat pada permukaan sel dan dalam cairan tubuh yang disebabkan oleh keragaman lektin yang terkait dengan spesifisitas pengikatannya terhadap karbohidrat sehingga sangat memungkinkan untuk digunakan di bidang kedokteran dalam era glycomics (Brooks et al., 2002., Varki et al., 1999).

Lektin (hemagglutinin) dari alga pertama kali dilaporkan melalui survei alga di Puerto Rico (Boyd et al., 1966).Penelitian selanjutnya di beberapa negara, antara lain Inggris (Blunden et al., 1975, 1978, Rogers et al., 1980), Jepang (Hori et al., 1981, 1986), Spanyol (Fabregas et al., 1985, 1992), Amerika (Chiles dan Bird 1989, Bird et al., 1993), dan Brasil (Ainouz dan Sampaio 1991, Ainouz et al., 1992,. Freitas et al., 1997) menunjukkan bahwa lektin (hemagglutinin) dapat ditemukan pada lebih dari dua ratus spesies alga (Hung et al., 2009).

Apabila lektin dari alga dibandingkan dengan lektin dari tanaman darat dan hewan yang telah berhasil dimurnikan dan dikarakterisasi dengan baik, memang masih ada keterbatasan informasi terkait dengan karakteristik kimia-biokimia dan molekulernya. Namun, akhir-akhir ini jumlah lektin dari alga yang telah berhasil dimurnikan dan dikarakterisasi mengalami peningkatan. Selama dua dekade terakhir dilaporkan bahwa lektin telah berhasil dimurnikan dari lebih dari lima puluh spesies alga (Sato dan Hori, 2009, Hung et al., 2009.). Penelitian akhir-akhir ini juga mengungkapkan bahwa lektin dari alga memiliki spesifisitas tinggi terhadap beberapa struktur oligosakarida tertentu dan dapat dikelompokkan menjadi beberapa jenis berdasarkan spesifisitas pengikatan terhadap oligosakarida (Sato et al., 2007, Hori et al., 2007). Oleh karena itu, alga berpotensi untuk menjadi sumber penemuan lektin baru yang dapat dimanfaatkan secara luas dalam penelitian dasar dan terapan antara lain di bidang kimia-biokimia, biologi molekuler, kesehatan, dan juga ilmu pangan. Namun demikian, terlepas dari kemajuan yang telah dicapai dalam karakterisasi kimia-biokimia dan molekuler lektin dari alga, informasi tambahan masih diperlukan untuk mendapatkan pemahaman yang lebih komprehensif tentang sifat, struktur, dan fungsi biologis serta peranan fisiologis lektin dari alga (Hori et al., 2000, 2007).

Lektin dari alga (khususnya alga merah) pada umumnya mempunyai karakteristik seperti berat molekul rendah, tidak memerlukan adanya kation divalen untuk aktifitas hemaglutinasinya, dan memiliki afinitas untuk glikoprotein tetapi tidak untuk monosakarida (Hori et al., 1990, 2000, 2007). Namun uniknya, beberapa lektin yang telah berhasil dimurnikan dan dikarakterisasi dari alga hijau genus Codium mempunyai kemiripan karakteristikdengan lektin yang berasal dari tanaman darat,antara lain mempunyai afinitas terhadap monosakarida dan berat molekul relatif besar, sehingga terkadang dapat dijumpai dalam bentuk polimerik dan memiliki struktur sub unit. Kemiripan karakteristik antara lektin dari alga hijau genus Codium dan tanaman darat ini mungkin disebabkan oleh kedekatan jarak evolusi antara dua kelompok ini. Hal ini dimungkinkan oleh karena alga hijau genus Codium berada pada posisi menengah di antara alga (alga coklat, merah, dan yang lainnya) dan tanaman darat dalam posisi filogenetiknya (Verbruggen et al., 2007). Selain itu, sejauh ini hanya beberapa lektin dari genus Codium seperti Codium fragile ssp. tomentosoides, $C$. fragile ssp. atlanticum, C. tomentosum, $C$. girrafa, dan C. barbatum(Rogers et al., 1986., Fabregas et al., 1988, Alvarez-Hernandez et al., 1999, Praseptiangga et al., 2012) yang berhasil dimurnikan dan dikarakterisasi secara parsial, sehingga dalam penelitian iniakan dilaporkan hasil penapisan lektin (hemagglutinin) dari alga hijau genus Codium dari persepektif bioprospeksi alga, khususnya alga hijau dari genus Codium sebagai kajian pendahuluan dalam upaya penemuan sumber lektin baru. 


\section{METODE PENELITIAN}

\section{Bahan dan Alat}

Beberapa spesies alga hijau dari genus Codium yaitu, Codiumintricatum, $C$. spongiosum, C. subtubulosum, C. arabicum, C. latum danC. cylindricum yang diperoleh dari hasil sampling di pantai dan perairan laut pulau Kyushu dan Shikoku, Jepang digunakan sebagai bahan baku utama dalam penelitian ini. Bahan pendukung yang digunakan antara lain larutan buffer phosphate buffered saline (PBS), ammonium sulfat $\left(\mathrm{NH}_{4}\right)_{2} \mathrm{SO}_{4}$, sodium azide $\left(\mathrm{NaN}_{3}\right)$, sodium klorida $(\mathrm{NaCl})$, darah (eritrosit) kelinci, trypsin, nitrogen cair, air miliQ, dan bahan kimia untuk pengujian protein. Semua bahan kimia yang digunakan dalam penelitian ini adalah analytical grade dengan tingkat kemurnian tertinggi.

Alat yang digunakan dapat dibedakan menjadi dua macam, yaitu alat yang digunakan untuk preparasi ekstrak alga dan presipitat ammonium sulfat, antara lain blender (Hamilton dan Waring), gunting, pinset, spatula, tabung nitrogen cair, gelas beker, gelas ukur, neraca, neraca analitik, magnetic stirrer, refrigerated centrifuged (tipe Sakuma dan Sorvall), centrifuge tubes, hot plate, $\mathrm{pH}$ meter, pipet, dialysis tubes, penjepit dialysis tubes, sample tubes dan alat yang digunakan untuk analisa, antara lain 96well microtiter $V$-plate, vortek, micro mixer, tabung reaksi, spektrofotometer UV-vis, inkubator, dan mikropipet.

\section{Tahapan Penelitian}

\section{Preparasi Ekstrak Alga dan Presipitat Ammonium Sulfat}

Sampel beku dari beberapa spesies alga hijau, Codium intricatum, $C$. spongiosum, C. subtubulosum, C. arabicum, C. latum, danC. Cylindricum dikeluarkan dari lemari pendingin suhu $-30^{\circ} \mathrm{C}$, dicairkan, dan kemudian ditimbang masing-masing 50 gram. Pengecilan ukuran dilakukan dengan memotong-motong sampel yang telah dipersiapkan dan selanjutnya digunakan blender serta ditambahkan nitrogen cair dengan maksud agar sampel lebih cepat menjadi bubuk dan homogen.
Proses ekstraksi dilakukan dengan cara menambahkan $20 \mathrm{mM}$ larutanphosphate buffer yang mengandung $0,85 \% \mathrm{NaCl}$ dan $0,02 \% \quad \mathrm{NaN}_{3}$ (PBSA, pH 7.0) ke dalam sampel yang telah menjadi bubuk dengan rasio 1:2 (b/v). Campuran sampel dan buffer PBSA kemudian diaduk dengan menggunakan stirer selama semalam pada suhu $4^{\circ} \mathrm{C}$. Setelah itu, campuran tersebut disentrifugasi $(13,500 \mathrm{~g})$ pada suhu $4^{\circ} \mathrm{C}$ selama 30 menit dan ammonium sulfat padat yang telah dihaluskan ditambahkan ke dalam supernatan yang diperoleh untuk mendapatkan konsentrasi akhir kejenuhan $75 \%$. Selanjutnya campuran disimpan semalam pada suhu $4^{\circ} \mathrm{C}$ dan disentrifugasi kembali $(13,500 \mathrm{~g})$ pada suhu $4^{\circ} \mathrm{C}$ selama 30 menit. Presipitat yang diperoleh kemudian dilarutkan kembali dengan penambahan buffer sesedikit mungkin dan didialisis dengan menggunakan PBSA. Setelah dialisis, fraksi bagian dalam (inner fraction) disentrifugasi lebih lanjut $(10,000 \mathrm{~g})$ pada suhu $4^{\circ} \mathrm{C}$ selama 30 menit dan supernatant yang diperoleh disebut sebagai fraksi kasar lektin atau sering disebut salting-out fraction. Salting-out fraction ini kemudian disimpan dalam lemari pendingin suhu $-30^{\circ} \mathrm{C}$ setelah digunakan untuk analisa lebih lanjut, yaitu uji aktifitas hemaglutinasi dan kandungan protein.

\section{Preparasi Trypsin-treated Rabbit Erythrocytes (TRBC)}

Trypsin-treated Rabbit Erythrocytes (TRBC) disiapkan dari darah (eritrosit) kelinci yang diperoleh dari laboratorium penelitian hewan (Hiroshima, Jepang). Eritrosit dicuci tiga kali dengan 50 volum saline $(0,85 \% \mathrm{NaCl})$ dan disuspensikan ke dalam saline untuk memberikan $2 \%(\mathrm{v} / \mathrm{v})$ suspensi dari native eritrosit. Kemudian 0,5 $\%(\mathrm{w} / \mathrm{v})$ trypsin dalam saline (1/10 bagian volum) ditambahkan ke dalam $2 \%$ suspensi dari native eritrosit dan campuran tersebut kemudian diinkubasi pada suhu $37^{\circ} \mathrm{C}$ selama 60 menit. Setelah itu, campuran dicuci empat kali dengan saline dan $2 \%$ suspensi TRBC dipersiapkan dalam saline. 


\section{Hemagglutination Assay}

Pengujian aktifitas hemaglutinasi ditentukan berdasarkan metode Hori et al. (1986).Aktifitas hemaglutinasi ini dilakukan dalam96-well microtiter V-plate dengan menggunakan TRBC dan dilakukan dengan tiga kali ulangan. Pengenceran dua kali lipat secara seri (masing-masing $25 \mu \mathrm{l}$ ) dilakukan dari sampel yang dianalisa dan dipersiapkan di dalam saline terlebih dahulu, kemudian ke dalam tiap sumuran ditambahkan $25 \mu 1$ TRBC. Microtiter plate kemudian diguncang perlahan dan merata serta diinkubasi pada suhu kamar selama 1 jam. Hemaglutinasi diamati secara makroskopik dan dinilai positif apabila lebih dari $50 \%$ dari TRBC dalam sumuran teraglutinasi. Aktifitas hemaglutinasi ini dinyatakan sebagai titer, yang berarti kebalikan dari pengenceran dua kali lipat tertinggi yang menunjukkan hemaglutinasi positif.

\section{Penentuan Kandungan Protein}

Kandungan protein ditentukan dengan metode Lowry et al. (1951) dengan menggunakan bovine serum albumin (BSA) sebagai standar dan dilakukan dengan dua kali ulangan.

\section{HASIL DAN PEMBAHASAN}

Aktifitas hemagglutinasi dan kandungan protein dari beberapa alga hijau genus Codium dapat dilihat pada Tabel 1.

Hasil pengujian aktifitas hemaglutinasi yang dilakukan pada beberapa fraksi kasar lektin (salting-out fraction) spesies alga hijau genus Codium menunjukkan bahwa lima spesies Codium intricatum, C. spongiosum, C. subtubulosum, $C$. arabicum, dan $C$. latum mampu mengaglutinasi trypsin-treated rabbit erythrocytes (TRBC). Aktifitas hemaglutinasi yang kuat diperlihatkan oleh Codum latum $\left(2^{9}\right.$ atau 512) dan Codium spongiosum $\left(2^{8}\right.$ atau 256). Sedangkan Codiumintricatum, Codium subtubulosum, dan Codium arabicum menunjukkan aktifitas hemaglutinasi yang relatif kuat, akan tetapi Codiumcylindricum tidak menunjukkan aktifitas hemaglutinasi pada pengujian ini (Tabel 1). Dari hasil pengamatan aktifitas hemaglutinasi tersebut, dapat diindikasikan bahwa Codium latum dan C. spongiosum mempunyai potensi yang lebih besar dibandingkan spesies alga hijau genus Codium yang diuji lainnya untuk dapat memasuki tahapan lanjut pemurnian lektin (hemagglutinin). Kandungan protein tertinggi diperlihatkan oleh Codium latum $(3.9 \mathrm{mg} / \mathrm{ml})$ (Tabel 1).

Sebagaimana telah diketahui bahwa karakteristik yang paling penting dari lektin adalah kemampuan mereka untuk mengikat karbohidrat dan mengaglutinasi sel. Aglutinasi ini disebabkan oleh fakta bahwa lektin setidaknya memiliki dua sisi pengikatan sehingga dapat berikatan silang dengan sel melalui interaksinya dengan karbohidrat pada membran sel (Sharon dan Lis, 2003). Sebagian besar peneliti telah mendeteksi lektin melalui penelitian mengenai aglutinasi dengan menggunakan eritrosit manusia dan hewan dan / atau sel lainnya. Oleh karena itu, pengujian aktifitas hemaglutinasi pada penelitian ini menggunakan eritrosit dari kelinci dengan perlakuan enzim tripsin (trypsin-treated rabbit erythrocytes) berdasarkan pertimbangan bahwa lektin (hemagglutinin) dari alga lebih sensitif terhadap eritrosit hewan, terutama eritrosit kelinci daripada eritrosit manusia dan perlakuan enzim yang dalam hal ini digunakan tripsin (meskipun enzim lain dapat digunakan, seperti misalnya papain) mengakibatkan sensitifitasnya menjadi semakin tinggi (Hori et al., 1988). Hal ini didukung dengan penelitian Hori et al. (1990) yang mengungkapkan bahwa ketika ekstrak dari spesies alga diuji aktifitas hemaglutinasinya terhadap native eritrosit dan berbagai perlakuan enzim (enzymetreated erythrocytes), mereka menunjukkan kecenderungan untuk menggumpalkan lebih kuat pada eritrosit, terutama eritrosit kelinci, yang sebelumnya telah dilakukan perlakuan dengan enzim (enzyme-treated erythrocytes), khususnya tripsin. Penelitian yang dilakukan oleh Blunden et al. (1975) juga menunjukkan bahwa lektin (hemagglutinin) dari sejumlah besar spesies alga dapat ditunjukkan pada saat eritrosit yang digunakan untuk mendeteksi aktifitas hemaglutinasinya telah 
Tabel 1. Aktifitas Hemaglutinasi dan Kandungan Protein Alga Hijau Genus Codium

\begin{tabular}{clcc}
\hline No. & \multicolumn{1}{c}{ Spesies alga } & $\begin{array}{c}\text { Aktifitas Hemaglutinasi } \\
(\mathbf{H A})^{\mathbf{a}}\end{array}$ & $\begin{array}{c}\text { Kandungan Protein } \\
\text { (mg/ml) }\end{array}$ \\
\hline 1. & Codium intricatum & 32 & 2.6 \\
2. & Codium spongiosum & 256 & 0.6 \\
3. & Codium subtubulosum & 64 & 2.2 \\
4. & Codium arabicum & 32 & 2.6 \\
5. & Codium latum & 512 & 3.9 \\
6. & Codium cylindricum & ${ }^{\mathrm{c}}$ & 1.3 \\
\hline
\end{tabular}

a Aktifitas Hemaglutinasi (HA), dinyatakan sebagai titer, yang berarti kebalikan dari pengenceran dua kali lipat tertinggi yang menunjukkan hemaglutinasi positif

${ }^{\mathrm{b}}$ Kandungan protein ditentukan dengan metode Folin-Lowry (1951)

${ }^{c}$ Tidak terdeteksi

diberi perlakuan dengan enzim, seperti papain.

Berdasarkan laporan yang disampaikan oleh Verbruggen et al. (2007), alga hijau genus Codium telah digunakan sebagai sumber senyawa bioaktif yang di antaranya berpotensi sebagai anti-cancer agents dan antibiotik. Lebih lanjut, terkait dengan kegunaan lektin dari alga hijau genus Codium, Wu et al. (1997) mengungkapkan bahwa $\mathrm{N}$-asetil galaktosamin spesifik lektin dari Codium fragile ssp. tomentosoides menunjukkan afinitas khusus pada forsmann antigen sugar chain yang merupakan penanda kanker dan dapat dimanfaatkan dalam bidang medis. Selain itu, sejauh ini baru beberapa lektin (hemagglutinin) yang berhasil dimurnikan dari alga hijau genus Codium, sehingga lektin dari genus Codium ini merupakan target yang menarik untuk dikaji lebih lanjut, khususnya yang terkait dengan aplikasinya di bidang kesehatan dalam era glycomics dan bidang pangan gizi, mengingat beberapa spesies dari genus ini dapat dikonsumsi sebagai bahan pangan, selain juga diharapkan dapat memberikan wawasan secara menyeluruh dan komprehensif untuk mengungkap hubungan evolusi antara alga dan tanaman darat.

\section{DAFTAR PUSTAKA}

Ainouz, I.L., Sampaio, A.H., 1991. Screening of Brazilian marine algae for hemagglutinins. Bot. Mar. 34, 211-214.

Ainouz, I.L., Sampaio, A.H., Benevides,

N.M.B., Freitas, A.L.P., Costa, F.H.F., Carvalho, M.C., Pinheiro-Joventino, F.,
1992.Agglutination of enzyme treated erythrocytes by Brazilian marine algae. Bot. Mar. 35, 475-479.

Alvarez-Hernandez, S., De Lara-Isassi, G., Arreguin-Espinoza, R., Arreguin, B., Hernandez-Santoyo, A., RodriguezRomero, A., 1999.Isolation and partial characterization of giraffine, a lectin from the Mexican endemic alga Codium giraffe Silva. Bot. Mar. 42, 573-580.

Bird, K.T, Chiles, T.C., Longley, R.E., Kendrick, A.F., Kinkema, M.D., 1993.Agglutinins from marine macroalgae of the Southeastern United States. J. Appl. Phycol. 5, 212-213.

Blunden, G., Rogers, D.J., Farnham, W.F., 1975. Survey of British seaweeds for hemagglutinins.Lloydia. 38, 162-168.

Blunden, G., Rogers, D.J., Farnham, W.F., 1978. Hemagglutinins in British marine algae and their possible taxonomic value.In: Irvine, D.E.G., Price, J.H. (eds), Modern approaches to the taxonomy of red and brown algae, pp 21-45. Academic, London.

Boyd, W.C., Almodovar, L.R., Boyd, L.G., 1966. Agglutinins in marine algae for human erythrocytes. Transfusion. 6, 8283.

Brooks, S.A., Dwek, M., Schumacher, U., 2002.Functional and molecular glycobiology. Garland Science. UK.

Chiles, T.C., Bird, K.T., 1989. A comparative study of the animal erythrocyte agglutinins from marine algae. Comp. Biochem. Physiol. B. 94, 107-111. 
Fabregas, J., Llovo, J., Muñoz, A., 1985. Hemagglutinins in red seaweeds. Bot. Mar. 28, 517-520. .

Fabregas, J., Muñoz, A., Llovo, J., Carracedo, A., 1988. Purification and partial characterization of tomentine.An $\mathrm{N}$-acetylglucosamine specific lectin from the green alga Codium tomentosum (Huds.)Stackh.J Exp. Mar. Biol. Ecol. 124, 21-30.

Freitas, A.L.P., Teixeira, D.I.A., Costa, F.H.F., Farias, W.R.L., Lobato, A.S.C., Sampaio, A.H., Benevides, N.M.B., 1997. A new survey of Brazilian marine algae for agglutinins. J. Appl. Phycol. 9, 495-501.

Hori, K., Miyazawa, K., Ito, K., 1981. Hemagglutinins in marine algae. Bull. Japan. Soc. Sci. Fish. 49, 793-398.

Hori, K., Miyazawa, K., Ito, K., 1986. Preliminary characterization of agglutinins from seven marine algal species. Bull. Jpn. Soc. Sci. Fish. 52, 323-331.

Hori, K., Oiwa, C., Miyazawa, K., Ito, K., 1988. Evidence for wide distribution of agglutinins in marine algae.Bot. Mar. 31, 133-138.

Hori, K., Miyazawa, K., Ito, K., 1990. Some common properties of lectins from marine algae. Hydrobiologia. 204/205, 561-566.

Hori, K., Matsubara, K., Miyazawa, K., 2000. Primary structures of two hemagglutinins from the marine red alga, Hypnea japonica.Biochim. Biophys. Acta 1474, 226-236.

Hori, K., Sato, Y., Ito, K., Fujiwara, Y., Iwamoto, Y., Makino, H., Kawakubo, A., 2007. Strict specificity for high mannosetype $N$-glycans and primary structure of a red alga Eucheuma serra lectin.Glycobiology. 17, 479-491.

Hung, L.D., Hori, K., Nang, Q., 2009.Screening and preliminary characterization of hemagglutinins in Vietnamese marine algae. J. Appl. Phycol. 21, 89-97.

Lowry, O.H., Rosebrough, N.J., Farr, A.L., Randall, R.J., 1951.Protein measurement with the folin phenol reagent. J. Biol. Chem.193, 265-275.
Praseptiangga, D.,Hirayama, M., Hori, K., 2012.Purification, characterization, and cDNA cloning of a novellectin from the green alga, Codium barbatum. Biosci. Biotechnol.Biochem. 76:805-811.

Rogers, D.J, Blunden, G., Topliss, J.A., Guiry, M.D., 1980. A survey of some marine organisms for haemagglutinins. Bot. Mar. 23:569-577.

Rogers, D.J., Loveless, E.W., Balding, P., 1986.Isolation and characterization of the lectins from subspecies of Codium fragile.In: Kilpatrick, D.C., Van Driessche, E., Bog Hansen, T.C. (eds.), Lectins: Biology, Biochemistry, Clinical Biochemistry, vol. 5, pp. 155-160. Walter de Gruyter, Berlin, Germany.

Sato, T., Hori, K., 2009.Cloning, expression, and characterization of a novel anti-HIV lectin from the cultured cyanobacterium, Oscillatoria agardhii.Fish. Sci. 75, 743753.

Sato, Y., Okuyama, S., Hori, K., 2007.Primary structure and carbohydrate binding specificity of a potent anti-HIV lectin isolated from the filamentous cyanobacterium, Oscillatoria agardhii. J. Biol. Chem. 282, 1102111029.

Sharon, N., Lis, H., 2003. Lectins $2^{\text {nd }}$ ed. Kluwer, The Netherlands.

Varki, A., Cummings, R., Esko, J., Freeze, H., Hart, G., Marth, J., 1999. Essentials of glycobiology.Cold Spring Harbor Laboratory Press. New York.

Verbruggen, H., Leliaert, F., Maggs, C.A., Shimada, S., Schils, T., Provan, J., Booth, D., Murphy, S., Clerck, O., Littler, D.S., Littler, M.M., Coppejans, E.., 2007. Species boundaries and phylogenetic relationships within the green algal genus Codium (Bryopsidales) based on plastid DNA sequences. Mol. Phyl. Evol. 44, 240-254.

Wu, A.M., Song, S.C., Chang, S.C., Wu, J.H., Chang, K.S., Kabat, E.A., 1997.Further characterization of the binding properties of a GalNAc specific lectin from Codium fragile subspecies tomentosoides.Glycobiology 7, 10611066. 